
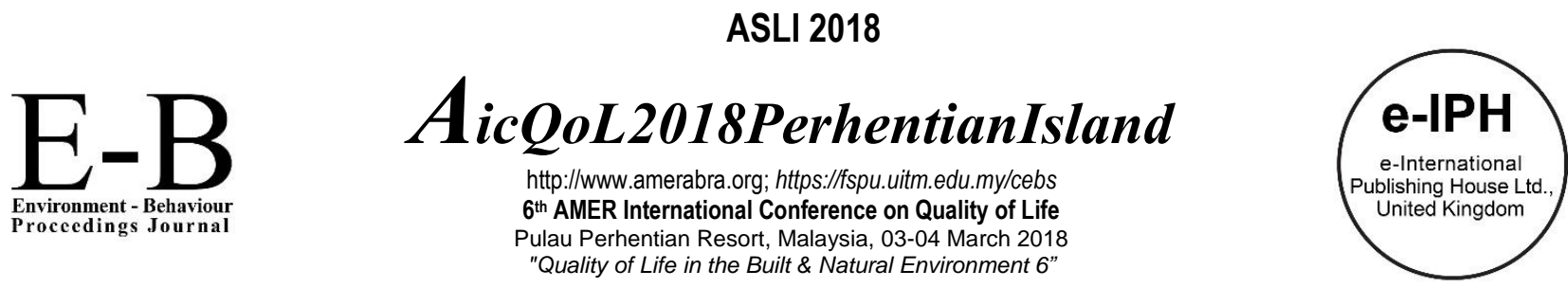

\title{
Ascertaining the Economic Sustainability of Heritage Property Market based on Sales Transaction Analysis
}

\author{
Normayuni Mat Zin, Suriatini Ismail, Fatin Afiqah Md. Azmi \\ Faculty of Architecture and Ekistics, Universiti Malaysia Kelantan, Bachok Campus, Karung Berkunci 01, 16300 Bachok, Kelantan \\ mayunimatzin@gmail.com \\ Tel: +010-5356369
}

\begin{abstract}
Increasing trend in property transactions can be used as an indicator of economic sustainability of an area. This paper analyses the transaction volumes and prices of pre-war shophouses in four historical areas in Malaysia in order to ascertain the state of economic sustainability of the heritage property markets. Secondary data for 2004 until 2017 were obtained from governmental sources and descriptive statistical analysis was undertaken. The results show evidence of increasing trend in the price per square foot for the shophouses in all the areas suggesting that there is economic sustainability of the heritage property markets in Malaysia.
\end{abstract}

Keywords: Economic sustainability; heritage, property market analysis; transaction price; transaction volume

eISSN: 2398-4287@ 2018. The Authors. Published for AMER ABRA cE-Bs by e-International Publishing House, Ltd., UK. This is an open access article under the CC BYNC-ND license (http://creativecommons.org/licenses/by-nc-nd/4.0/). Peer-review under responsibility of AMER (Association of Malaysian Environment-Behaviour Researchers), ABRA (Association of Behavioural Researchers on Asians) and cE-Bs (Centre for Environment-Behaviour Studies), Faculty of Architecture, Planning \& Surveying, Universiti Teknologi MARA, Malaysia.

DOI: https://doi.org/10.21834/e-bpj.v3i7.1299

\subsection{Introduction}

Heritage is related to sustainable through conservation, preservation practices and maintenance management in order to prevent the property from deterioration, extend the building life and basic functions as well as revitalization of these property values (Nor Aini, Lim, Lee, \& Tan, 2007) as it represents something worth remembering about the legacy from the past, being of cultural significance for today that should be passed to future generations (Hasif Rafidee Hasbollah, 2014; UNESCO, 2017). There is a close relationship between heritage and sustainability of urban areas since UNESCO (2015) has confirmed that it contributes positively towards a sustainable city. Heritage plays a vital role to the economy of the nation notably to accommodate the human needs and improving the citizens' standards of living (Tweed and Sutherland, 2007), provide favourable investment and also generate income to gain the quality of life for all citizens in income and profit-generating as well as for the community well-being (Necissa, 2011).

\subsection{Background of the Study}

Fascinating aspects of Malaysian old and historic cities are they have their own unique features, historical significance of urban development and its evolving culture which is demonstrated through its heritage property. This country is blessed with a rich legacy of heritage treasures and highly valuable assets with unique architectural and historical values as well as its deliverance of their cultural identity of a city all over the country and its people (Ahmad Bashri Sulaiman, Shuhana Shamsuddin, Sharifah Lily Norbienna, \& Markarius Anwar, 2007; Nor Aini et al., 2007). There are hundreds of heritage properties including public (i.e. railway stations, prisons, museum, palace of worship, palace, pre-war institution buildings, monument and etc) and private (i.e. pre-war shophouses, pre-war housing) which are commonly found in many historic cities throughout Malaysia (Ahmad Bashri Sulaiman et al., 2007; Federal Department of Town and Country Planning, 2009). Besides that, these buildings strongly attract foreign and local tourists to visit the areas, and thus, generate

eISSN: 2398-4287@ 2018. The Authors. Published for AMER ABRA cE-Bs by e-International Publishing House, Ltd., UK. This is an open access article under the CC BYNC-ND license (http://creativecommons.org/licenses/by-nc-nd/4.0/). Peer-review under responsibility of AMER (Association of Malaysian Environment-Behaviour Researchers), ABRA (Association of Behavioural Researchers on Asians) and cE-Bs (Centre for Environment-Behaviour Studies), Faculty of Architecture, Planning \& Surveying, Universiti Teknologi MARA, Malaysia.

DOI: https://doi.org/10.21834/e-bpj.v3i7.1299 
potential income in the tourism sector. On the other hand, conservation, preservation as well as maintenance works of the heritage property constitute an essential driver for the economic development whereby its possibility to generate income from cultural assets, creating the job employment, reduce poverty, stimulates enterprise development, foster private investment and generate resources for environmental and cultural conservation (Baycan \& Girard, 2011). Hence, the role of heritage property by its preservation and conservation activities towards economic sustainability must be considered and emphasized. This study responded to the statement and aimed to ascertain the state of economic sustainability of heritage property contribution within historic areas from the perspective of its property values. In order to achieve a sustainable development in terms of economic perspective, it is relevant to understand the behaviour of heritage property market. This study extends Rypkema, Cheong and Mason (2011)'s study by providing empirical evidence and analysis of heritage property market. Furthermore, this study is motivated by Guzman, Pereira Roders and Colenbrader (2017) who claimed that studies on cultural heritage and sustainability were given lack of attention. This paper is structured as follows; section two is a review of previous literatures and provides justification measurement for heritage property valuation. Section three is the methodology section followed by the findings of this study in section four. Section five discussed the findings as well as to frame objective of this study. Section six concludes this study and offers the recommendation for future study.

\subsection{Literature Review}

Generally, there is growing recognition and acknowledgement of heritage role in promoting sustainability within the context of urban economic. Hence, many scholars (e.g. Berthold, Rajaonson, and Tanguay, 2015; Sabou, 2012; Necissa, 2011; Liusman, Ho, and Ge, 2013; Rypkema, Cheong and Mason, 2011; Baycan and Girard, 2011; Gilderbloom, Hanka, and Ambrosius, 2009; Stubbs, 2004; Listokin, Listokin, and Lahr, 1998) developed several main indicators of heritage property contribution towards economic sustainability. Extensive review from the abovementioned literature found that there are four main indicators highlighted such as i) employment/job creation; ii) property values; iii) heritage tourism, and iv) centre city or main street revitalization. In respond to the issues, Rypkema et al., (2011) conducted a systematic evaluation of the indicators from the perspective of academia, practitioners and international institutions, whereby three specific steps were taken by the scholars. Firstly, an intensive literature review was conducted from academic papers and other documents related to the topic. Secondly, an international symposium on the economics of historic preservation was held at the University Pennsylvania's School of Design and thirdly, a series of interview was conducted among experts in the federal and state agencies, national education/advocacy preservation community, and private sector.

For the purpose of this study, among four main indicators highlighted previously, we draw attention to research on the property values of heritage property. Property values are one of the most emphasized indicators or measurement among the scholars of heritage property contribution to an urban economic sustainability. Hence, the level of economic sustainability can be dictated by the performance of the heritage property market within the historic districts. But then, there arises a question of what and how basis is it to be measure? Although there are varieties of valuation approaches which applied to heritage property previously conducted around the world, however; which one is the method most appropriate and deliver a robust analysis? Research conducted by Rypkema et al., (2011) offers the justification of what and how the measurement of the impact on property values attributable to be located within a local historic and or National Register Historic District. However, finding from previous studies, there has been limited publication of a robust analyses or empirical findings found by using variety metric of measurement for measuring the performance of heritage property market. Most empirical studied were using hedonic pricing method for analysis to associate the preservation of heritage property within historic district designation on property values. The findings indicated that there is no conclusive result either positive or negative correlation on the established relationship. This study fulfils the gap by identifying the heritage property contribution from its property values perspective towards economic sustainability in Malaysian perspective. Even though Nor Aini et al., (2007) investigated the urban conservation impact on heritage property market in George Town, Penang by using the transaction counts numbers and transaction values of heritage property, the study being done was before the declaration of George Town as historic designation city by UNESCO. Overall, the metrics used for measurement to determine the impact of heritage on property values are summarized in Table 1.

Table 1. Recommended property value measurement of historic preservation for economic sustainability

\begin{tabular}{|c|c|c|c|}
\hline $\begin{array}{l}\text { Economic } \\
\text { Sustainability } \\
\text { Indicator }\end{array}$ & What should be measured & How the property values should be measured & Author (s)/ (year) \\
\hline \multirow[t]{2}{*}{$\begin{array}{l}\text { Property } \\
\text { Values }\end{array}$} & $\begin{array}{l}\text { Heritage property value } \\
\text { movements }\end{array}$ & $\begin{array}{l}\text { i. Year-to-year change in property value within historic } \\
\text { districts as compared to property value change in the rest } \\
\text { of the local market not within historic districts } \\
\text { ii. Percentage change in per-square-foot value of properties } \\
\text { within local/National historict districts }\end{array}$ & $\begin{array}{l}\text { Nor Aini et al., (2007); } \\
\text { Rypkema et al., } \\
\text { (2011) }\end{array}$ \\
\hline & $\begin{array}{l}\text { Heritage "premium" paid for } \\
\text { properties within historic } \\
\text { districts }\end{array}$ & $\begin{array}{l}\text { i. Application of hedonic pricing method and spatial hedonic } \\
\text { method } \\
\text { ii. Determine what is the difference in value (if any, and if } \\
\text { positive or negative) for properties within historic districts } \\
\text { as compared to similar properties not within historic } \\
\text { districts after all other variables in value contribution have } \\
\text { been accounted for. } \\
\text { iii. Most of the variables between properties (such as lot size, } \\
\text { floor area, number of room, number of bathroom, etc) are } \\
\text { usually included in the property records }\end{array}$ & $\begin{array}{l}\text { Asabere, Hackey, } \\
\text { and Grubaugh, 1989; } \\
\text { Asabere and } \\
\text { Huffman, (1991); } \\
\text { Lazrak, Nijkamp, } \\
\text { Rietveld, and } \\
\text { Rouwendal, (2014); } \\
\text { Leichenko, Coulson, } \\
\text { and Listokin, (2001); } \\
\text { Rypkema et al., } \\
\text { (2011) }\end{array}$ \\
\hline
\end{tabular}


Annual volume of heritage property sale transactions Number of re-sale of same property iv. Assed value database facilities by using GIS representation of findings

Analysis of increasing or decreasing annual volume of sale transactions of heritage property

Analysis of sale transaction number of similar property
Nor Aini et al., (2007)

Rypkema and

Cheong (2011)

\subsection{Methodology}

This study is quantitative method in order to successfully ascertain the heritage property market within historic designation district towards economic sustainability. For data analysis technique, this study solely applies two metrics as has been highlighted previously i.e annual volume of heritage property sales transaction analysis (Nor Aini et al., 2007; Rypkema et al., 2011) and heritage property transaction value/price movements/trend (Nor Aini et al., 2007). The most sophisticated analysis that has been widely used in heritage property value studies is known as hedonic pricing method. This method identified the individual components of a property and each component's contribution to the overall property value. However, this method was excluded from this analysis since its limitation of data provided in the sale transactions data whereby the data or the components of the property need a comprehensive list of variables, and basically it includes the main structural and transactional related attributes. However, other researchers have more comprehensive study that incorporates spatial statistics such as population density, distance to the city centre, percentage ethnic and others. The sale transactions data have been collected from secondary sources through the means of documentary analysis in digital form. Data of sale transactions volumes was gathered from Annual Property Market Report published by Malaysian Valuation and Property Services Department (VPSD) and sales transaction data of heritage property collected from the Malaysian Valuation and Property Services Department, Putrajaya and Kuala Terengganu Branch for a period of thirteen and a half (13 $1 / 2)$ years from 2004 to a half year of 2017. According to Rypkema et al., (2011), transaction data such as market transaction is more reliable than census data for measuring the property values. The raw data from VPSD branches of Putrajaya and Kuala Terengganu were filtered subject to an extensive checking and management in order to create a suitable data for this study. Consequently, a few problems arise including the inaccurate data, and missing or incomplete data but these technical constraints which could be handled by discarding or leaving out the data (Hair Jr., Black, Babin, \& Anderson, 2010). The study areas comprise four historic areas in Malaysia i.e. George Town, Malacca City, Kota Bharu and Kuala Terengganu and these areas were selected due to their historical background factors, strategic geographical location as well as their distribution of pre-war shophouses. Distinctive uniqueness of their culture and history of the past has qualified George Town and Malacca to be gazetted as Malaysian historical cities by UNESCO World Heritage Site (WHS) on 7th July 2008 (UNESCO, 2017 ). Kota Bharu was officially declared as local designation as the city of culture by Sultan Kelantan on 25th July 1991 (Yasmin Mohd Fauzi \& Juliza Mohamad, 2014) whilst Kuala Terengganu was awarded as "Waterfront Heritage City" on 1st January 2008 along its geographical location facing South China Sea (Federal Department of Town and Country Planning, 2009). Heritage property is mostly dominated by pre-war shophouses which transacted/traded in the market, and thus this type of property has been selected as the sample in this study.

\subsection{Findings}

\subsection{Annual Volume of Pre-War Shophouses Sale Transactions in George Town, Malacca City, Kota Bharu and Kuala Terengganu}

Table 2 shows the sale transactions of pre-war shophouses volume within the four study areas. George Town, Malacca City, Kota Bharu and Kuala Terengganu recorded 1,697, 339, 31 and 16, respectively which accounting for $54.51 \%, 42.80 \%, 88.57 \%$ and $21.62 \%$, respectively of overall total transaction volumes in Penang, Malacca, Kelantan and Terengganu within the period of 2003 to $\mathrm{H} 12017$. George Town and Kota Bharu indicated most of the transacted of pre-war shophouses were in the cities. In term of measurement of year to year transactions volume changes within the period of study, George Town and Malacca city recorded the highest number of transaction in 2011 and 2010 with 228 and 44 transactions, respectively. Thus, the year of 2010 and 2011 were being particularly good years for dynamic market of the heritage property in both cities. On contrary, Kota Bharu and Kuala Terengganu did not show major changes of their transactions volume with static and stable movements and recorded the highest of 4 transactions in 2004 and 2005. However, there is no consistent and linear improvement of the transaction number within the period, thus; this study proceeds with the analysis of pre-war shophouses price and price per square foot movements/trend.

Table 2. Recommended property value measurement of historic preservation for economic sustainability Pre-War Shophouses Sale Transactions Volume

\begin{tabular}{llll}
\hline George Town & Malacca City & Kota Bharu & Kuala Terengganu
\end{tabular}




\begin{tabular}{|c|c|c|c|c|c|c|c|c|c|c|c|c|}
\hline Year & 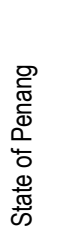 & 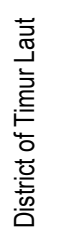 & 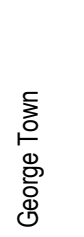 & 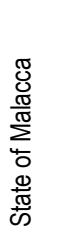 & 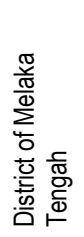 & 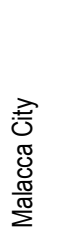 & 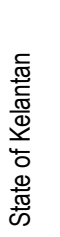 & 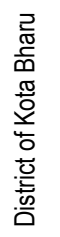 & 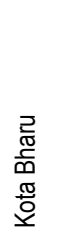 & 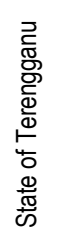 & 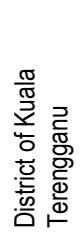 & 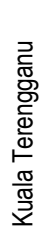 \\
\hline 2004 & 194 & 191 & 7 & 45 & 39 & 8 & 5 & 5 & 4 & 8 & 7 & 4 \\
\hline 2005 & 177 & 173 & 20 & 45 & 35 & 27 & 4 & 4 & 4 & 8 & 7 & 4 \\
\hline 2006 & 211 & 191 & 129 & 27 & 15 & 8 & 4 & 2 & 2 & 8 & 7 & 1 \\
\hline 2007 & 217 & 210 & 155 & 50 & 38 & 21 & 2 & 2 & 2 & 0 & 0 & 0 \\
\hline 2008 & 247 & 241 & 131 & 52 & 40 & 23 & 0 & 0 & 0 & 9 & 9 & 0 \\
\hline 2009 & 310 & 302 & 219 & 72 & 66 & 33 & 2 & 2 & 2 & 7 & 2 & 0 \\
\hline 2010 & 341 & 333 & 211 & 83 & 76 & 44 & 3 & 3 & 3 & 3 & 3 & 1 \\
\hline 2011 & 345 & 339 & 228 & 87 & 79 & 41 & 2 & 2 & 2 & 8 & 8 & 1 \\
\hline 2012 & 242 & 242 & 156 & 75 & 65 & 26 & 0 & 0 & 5 & 2 & 1 & 0 \\
\hline 2013 & 304 & 292 & 183 & 66 & 60 & 39 & 4 & 4 & 4 & 3 & 3 & 2 \\
\hline 2014 & 184 & 176 & 90 & 58 & 51 & 27 & 3 & 3 & 3 & 10 & 7 & 0 \\
\hline 2015 & 173 & 160 & 100 & 49 & 40 & 18 & 0 & 0 & 0 & 3 & 2 & 0 \\
\hline 2016 & 120 & 108 & 53 & 60 & 56 & 19 & 3 & 3 & 3 & 1 & 1 & 1 \\
\hline $2017(\mathrm{H} 1)$ & 48 & 46 & 15 & 23 & 21 & 5 & 3 & 3 & 2 & 4 & 3 & 2 \\
\hline Total & 3,113 & 3,004 & 1,697 & 792 & 681 & 339 & 35 & 33 & 31 & 74 & 60 & 16 \\
\hline
\end{tabular}

(Sources: Valuation and Property Services Department, 2004-H1 2017)

\subsection{Pre-War Shophouses Price and Price per Square Foot Movements/Trend in George Town, Malacca City, Kota Bharu and Kuala Terengganu}

Secondly, the data analyzed the price of pre-war shophouses in order to ascertain the state of economic sustainability of heritage property contribution by using descriptive statistics comprising the mean, minimum and maximum values of its prices and prices per square foot. The percentage change in price per-square-foot was also offered in the analysis. Table 3 shows pre-war shophouses price and price per square- foot movements in the four study areas within study period. The prices in George Town have been spiked upward since 2011 after declaration of George Town as a UNESCO Heritage Site in 2008. The market is observed to have stable trend across the board in mean price and price per square foot until H1 2017. Year 2011 saw a huge jump in mean of price appreciation from RM836,000 in 2010 to RM 1,070,000 whilst the average price per square-foot increase from RM413 to RM543 per square-foot accounting of $31.48 \%$ changes. Therefore, the price and price per square-foot of heritage property have impressively increased over the years. Within the period, there was a record of high value per square foot in George Town in 2009 with RM3,300, followed by 2011 (RM3,100) and 2016 (RM2,950). Similar to George Town, pre-war shophouses price in Malacca is dynamic which have spiked upwards since 2008 after the declaration. Year 2010 until 2012 saw huge jump in mean of price appreciation from RM689,000 to RM1,040,000 and maximum of price appreciation jump from RM1,000,000 to RM5,100,000 in 2012 whilst the average price per square-foot increase from RM245 to RM744 per square-foot accounting of total $203.67 \%$ of changes within the period. However, the price is slightly declined in maximum price per square foot, but still remains stable for minimum and mean price per square foot. Within the $13 \frac{1 / 2}{2}$ year periods, Malacca recorded high value per square foot in 2015 with RM2,000 per square-foot. On the contrary, the sub-market of pre-war shophouses in Kota Bharu and Kuala Terengganu were generally unstable and no major changes. Mean price accounting of $22.45 \%$ of changes, minimum price ( $25 \%$ of changes) and maximum price $(20 \%$ of changes) in Kota Bharu along the period (2003 $-\mathrm{H} 12017)$. However, in terms of price per square foot, the minimum of property increased by twofold whilst maximum and mean still remain the same. Kuala Terengganu recorded downward trends for price per square foot between 2003 to 2006 and upward trends to 2013 and remain slowly down recently. Market value of the heritage property in both areas is unstable due to limited volume of transactions and sometimes there is no transaction in certain years. Lack of transaction volume will lead to unstable market price which ultimately arises thin market issues that will finally lead to bias in property valuation. This finding is supported by Junainah, Hishamuddin, and Suriatini (2011).

The current range (in $\mathrm{H} 12017$ ) of transacted prices per square-foot in George Town are between RM345 to RM1,800 and the average price per square-foot is between RM1,000 to 1,200. Malacca recorded lower price than George Town with RM120 to RM900 whilst Kota Bharu recorded a range from RM375 to RM390. Kuala Terengganu recorded higher price than Kota Bharu with a range from RM440 to RM 510. The prices are depending on the characteristics and specific location of the property since the pre-war properties are located in the main tourist attraction areas due to the unique historical and architectural styles that usually fetch higher prices. Properties located at the secondary roads tend to have lower prices if compared to properties located at the main road. To sum up, heritage property market in the study areas shows upward trends along the review period of $13 \frac{1}{2}$ years ( 2004 to H1 2017) due to macro and microeconomic factors. Nowadays, the heritage properties in George Town and Malacca are great places for fostering private investment. The analyses show that the heritage property in George Town enjoyed a surge in minimum price, increased by triple to 
fourfold, maximum price, increased by twentyfold, mean price increased by eightfold, and mean price per square foot increased by fivefold to sixfold, compared to year 2004. The heritage property in Malacca enjoyed a surge in minimum price, increased by double to threefold, maximum price increased by sixfold, mean price and mean price per square foot increased by fourfold, respectively compared to year 2004 .

\subsection{Discussion and Analysis}

Nor Aini et al., (2007) suggested a sustainable or viable property market based on Shankland's study through two measurement includes; i) increasing number or volumes of property transactions and ii) increase the value of the property traded. Hence, two main findings offered in this study is in line with Nor Aini et al., (2007). Pursuant to annual volume sale transactions analysis, surprising investigation which emerges from the sales transaction data does not prove that the heritage property market is sustained for a longer period (due to not consistent and linear improvement) notably in Kota Bharu and Kuala Terengganu whereby the thin market operates. This finding is in line of Nor Aini et al., (2007), however; the result was contradictory from their first proposal. The pre-war shophouses sale transaction volumes movements as depicted in Figure 2 represents its complete cycle. As Richard Grover and Christine Grover (2013) stated that the persistence property cycle in four (4) stylized form which passing through of recovery, prosperity, recession and depression, reflection of sinusoidal waves of boom and bust behavior in the market and influenced by macroeconomic, microeconomic, finance and management factors (Grenadier, 1995; Kamarudin, Ismail, Mohd Ali, Sipan, \& Raji, 2014).

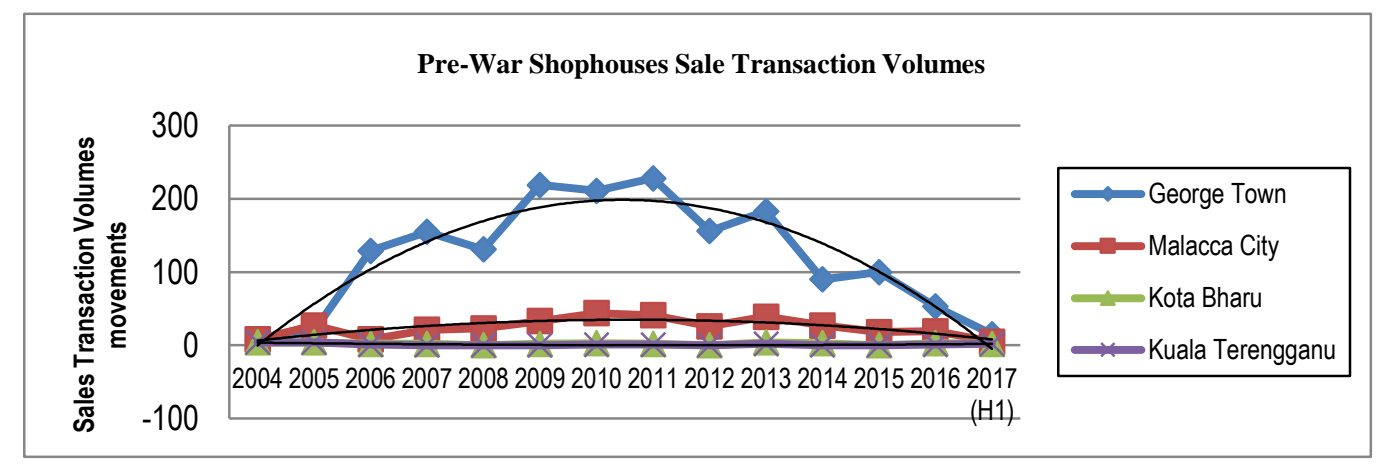

Fig. 2: Sale transactions volume of pre-war shophouses within the four study areas (Source: Valuation and Property Services Department, 2004-H1 2017)

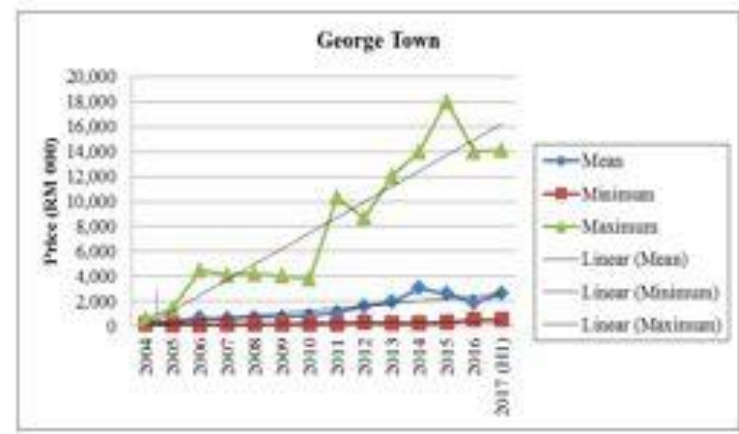

(a)

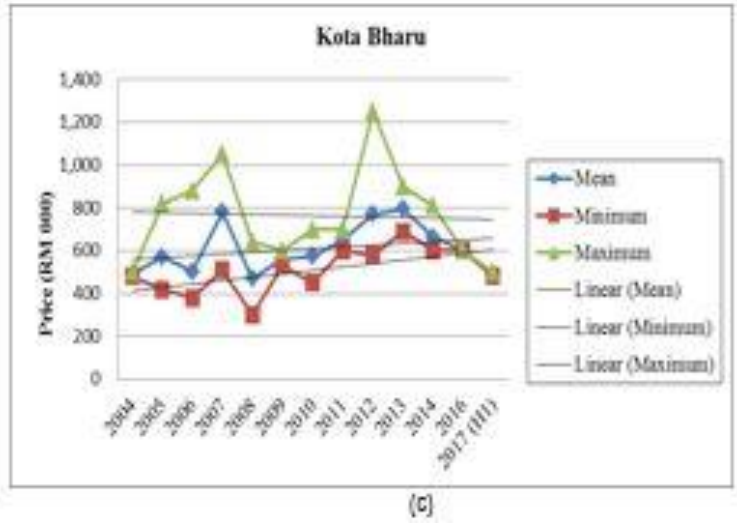

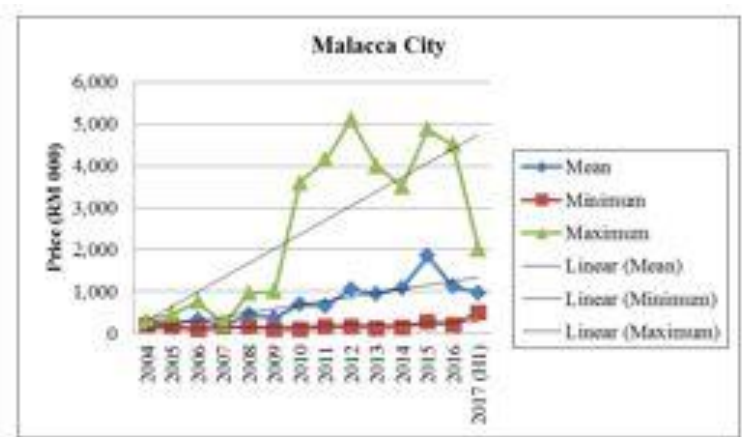

(b)

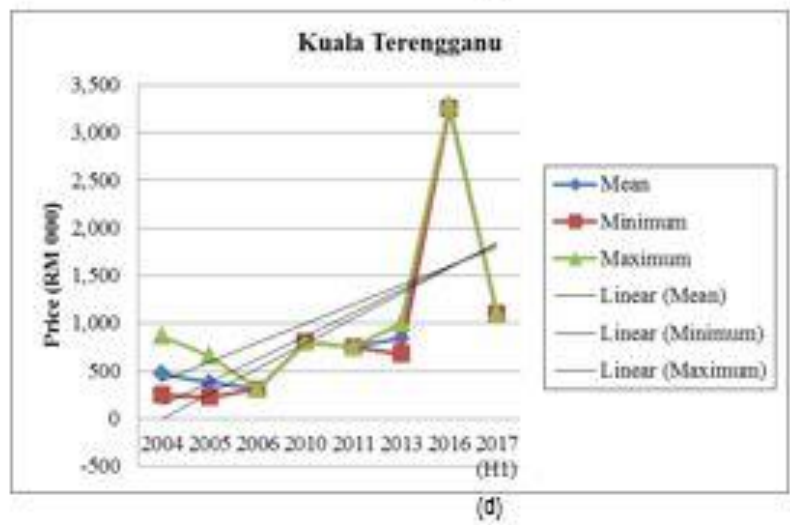

Fig. 3: (a)(b)(c)(d) Pre-war shophouses price movements/trend in George Town; Malacca City, Kota Bharu and Kuala Terengganu. (Source: Valuation and Property Services Department, 2004-H1 2017) 
On the contrary, investigation of pre-war shophouses price and price per square foot and evidence of its movements/trend as exhibits in Figure 3 and 4 suggests that the heritage property market in four areas of study were generally able to sustain its previous high price and upward trends within the period under studied. This finding is consistent with the findings of past studies by Nor Aini et al., (2007) which revealed that heritage property market in terms of its price movements for a long period is sustainable even though any conservation policies of heritage property was introduced.

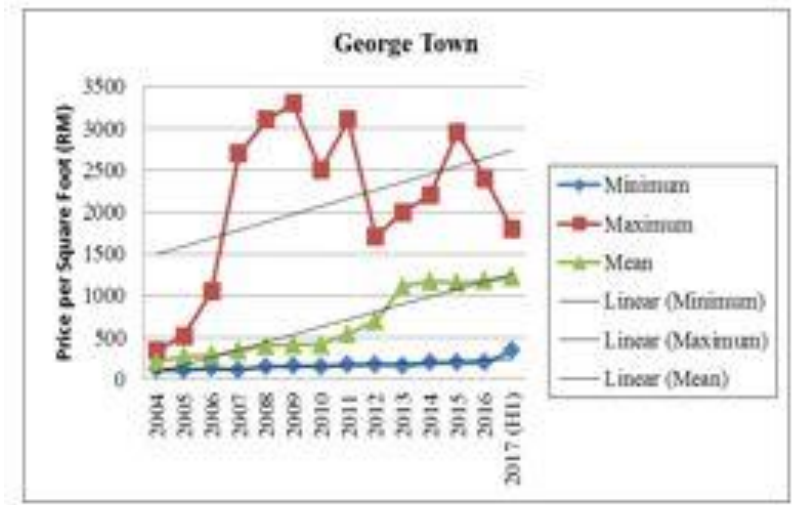

(a)

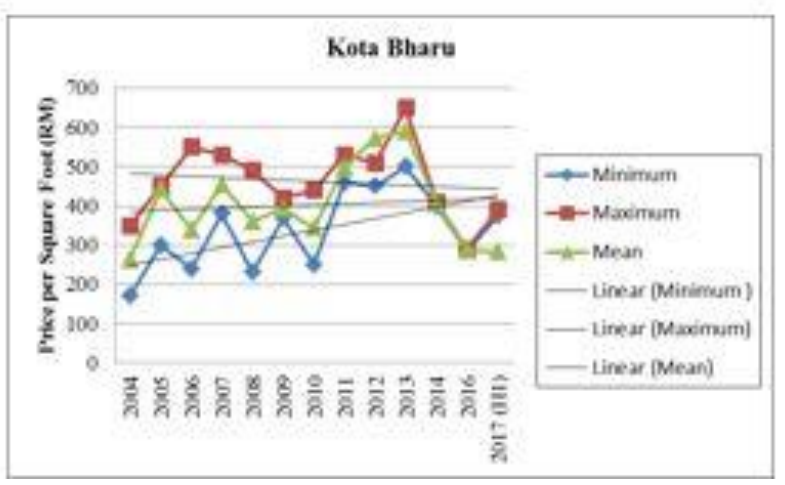

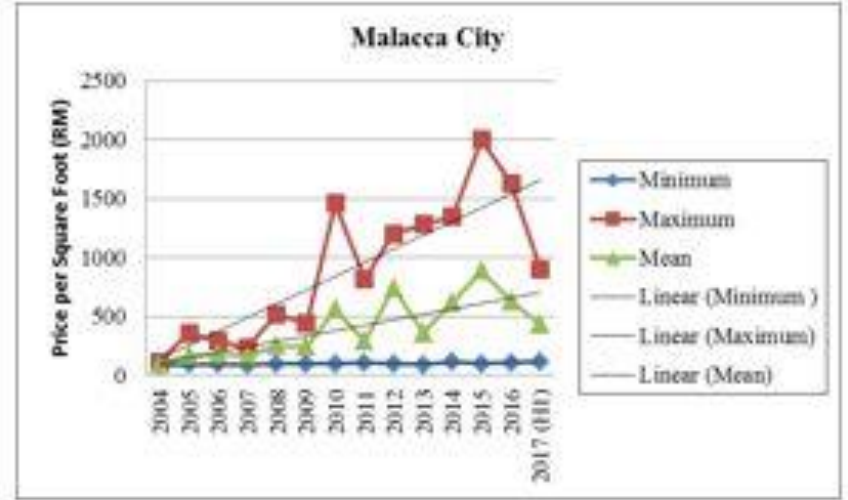

(b)

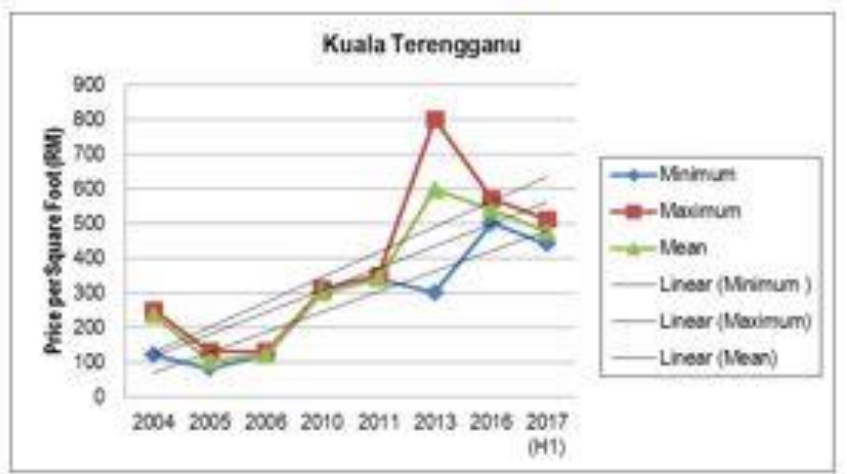

Fig. 4: $(a)(b)(c)(d)$ Pre-war shophouses price per square foot movements/trend movements/trend in George Town; Malacca City, Kota Bharu and Kuala Terengganu.

(Source: Valuation and Property Services Department, 2004-H1 2017)

In other perspective, the data of heritage property values are greatly important in the measuring of its contribution to the economic sustainability. The outcome of this study meets the need of several issues arise in Rypkema et al., (2011) including quantifiable metrics in ascertaining the economic sustainability of heritage property contribution by using reliable, sustainable and annualized information. Hence, this source of sale transactions data offers strength measurable for this study. Hence, evidence from the heritage property market based on sale transactions analysis offers a finding of this research which ascertains that heritage property often shows positive connection and closeness towards economic sustainability as well as to make this finding in line with the view of Rypkema et al., (2011). Heritage property market of price movements/trend as depicted in Figure 3 and 4 show a stable and sustainable movements with high demand, determined by a few factors influenced including its good strategies of preservation and maintenance works. The preservation and conservation activities within the historic areas in the study areas contribute to the model of historic urban landscape ultimately increasing long-term sustainability. Furthermore, the uniqueness of these properties located in historic areas constitutes as engine for economic development and contributes as "quality of place" as highlighted by Baycan and Girard (2011) which possibility in generating income from its cultural assets, creates more employment opportunities, attractive natural and built environments, diverse range of people and lifestyle.

\subsection{Conclusions and Recommendations}

This paper ascertained the contribution of heritage property and it's related to sustainable of economic development notably in Malaysia historic areas. This study provided the evidence of Rypkema et al., (2011) by conducting an observation and investigation of heritage property market based on sale transaction analysis. Analyses of annual volume sale transactions of pre-war shophouses in George Town, Malacca City, Kota Bharu and Kuala Terengganu and its price and price per square foot movements/trend were applied and, hence; this study suggests that the heritage property market in four areas of study were generally stable and sustainable. The property enjoyed high prices and upward trends for a long period. These historic cities like George Town and Malacca have become great places which in turn, can increase local attractiveness and generate significant returns on investments due to their unique history and culture. 
This opportunity may contribute to the sustainability of economic benefits. Theoretically, this study supports past literature in terms of the importance and contribution of heritage property towards economic sustainability. Practically, it also serves as useful tool for policy makers and government bodies in assessing the performance of economic sustainability generated by the heritage property, as well as a benchmark to monitor equity investment for investors. The present review provides an opportunity for future research to the enhancement of current method and specification of an appropriate/ effective method estimation of heritage property valuation using spatial hedonic model as have been suggested by the previous literatures in order to deliver more robust and reliable analysis. This method isolates the impact of specific variables that make up the price which is reasonably applied for heritage property valuation as that approach could be achieved for the betterment of our quality of life.

\section{Acknowledgement}

The author would like appreciates the financial support from Fundamental Research Grant Scheme (FRGS: R/FRGS/A02.00/00829A/002/2016/000371) under Ministry of Education (MOE) and sales transaction data sharing from National Property Information Centre (NAPIC), which made this research possible.

\section{References}

Ahmad Bashri Sulaiman, Shuhana Shamsuddin, Sharifah Lily Norbienna, \& Markarius Anwar. (2007). Conceptual New Model of City/Town Based on the Traditional Urban Form. Johor Bahru, Johor, Malaysia.

Asabere, P. K., Hackey, G., \& Grubaugh, S. (1989). Architecture, Historic Zoning, and the Value of Homes. Journal of Real Estate Finance and Economics, 195, 181195.

Asabere, P. K., \& Huffman, F. E. (1991). Historic Districts and Land Values. Journal of Real Estate Research, 6(1), 1-7.

Baycan, T., \& Girard, L. F. (2011). Heritage in socio-economic development: direct and indirect impacts. In COMOS 17th General Assembly (pp. 857-860). Paris, France, 27 November.

Berthold, É., Rajaonson, J., \& Tanguay, G. A. (2015). Using sustainability indicators for Urban Heritage management: a review of 25 case studies. International Journal of Heritage and Sustainable Development, 4(1), 23-34

Federal Department of Town and Country Planning. (2009). Urban Morphology of Bandar Kuala Terengganu.

Gilderbloom, J. I., Hanka, M. J., \& Ambrosius, J. D. (2009). Historic preservation's impact on job creation, property values, and environmental sustainability. Journal of Urbanism: International Research on Placemaking and Urban Sustainability, 2(2), 83-101.

Grenadier, S. R. (1995). The Persistence of Real Estate Cycles. Journal of Real Estate Finance and Economics, 10, 95-119.

Guzman, P. C., Pereira Roders, A. R., \& Colenbrander, B. J. F. (2017). Measuring links between cultural heritage management and sustainable urban development: An overview of global monitoring tools. Cities, 60, 192-201.

Hair Jr., J. F., Black, W. C., Babin, B. J., \& Anderson, R. E. (2010). Multivariate Data Analysis (7th Editio). New Jersey: Prentice-Hall International,Inc.

Hasif Rafidee Hasbollah. (2014). A Theoretical Framework for Conserving Cultural Values of Heritage Buildings in Malaysia from the Perspective of Facilities Management. PhD thesis, University of Salford, UK.

Junainah, M., Hishamuddin, M. A., \& Suriatini, I. (2011). The Existence and Implications of Thin Real Estate Market. International Journal of Trade Economics and Finance, 2(5), 376-380.

Kamarudin, N., Ismail, S., Mohd Ali, H., Sipan, I., \& Raji, F. (2014). An overview of the application of property market modelling in Malaysia. Jurnal Teknologi, 71(4), 167173.

Lazrak, F., Nijkamp, P., Rietveld, P., \& Rouwendal, J. (2014). The market value of cultural heritage in urban areas: an application of spatial hedonic pricing. Journal of Geographical Systems, 16, 89-114.

Leichenko, R. M., Coulson, N. E., \& Listokin, D. (2001). Historic Preservation and Residential Property Values: An Analysis of Texas Cities. Urban Studies, 38(11), 19731987.

Listokin, D., Listokin, B., \& Lahr, M. (1998). The Contributions of Historic Preservation to Housing and Economic Development. Housing Policy Debate, 9(3), $431-478$.

Liusman, E., Ho, D. C. W., \& Ge, J. X. (2013). Indicators for Heritage Buildings Sustainability. CESB 2013 PRAGUE - Central Europe Towards Sustainable Building 2013: Sustainable Building and Refurbishment for Next Generations.

Mori, K., \& Yamashita, T. (2015). Methodological framework of sustainability assessment in City Sustainability Index (CSI): A concept of constraint and maximisation indicators. Habitat International, 45(1), 10-14.

Necissa, Y. (2011). Cultural heritage as a resource: Its role in the sustainability of urban developments. The case of Tlemcen, Algeria. Procedia Engineering, 21, 874882.

Nor Aini, Y., Lim, Y. M., Lee, L. M., \& Tan, S. F. (2007). Urban Conservation as a Development Strategy to Revitalize Real Estate Market: An Analysis of Property Transactions in Georgetown Penang. Journal of Construction in Developing Countries, 12(2), 43-61. 
Richard Grover, \& Christine Grover. (2013). Property Cycles. Journal of Property Investment \& Finance, 31(5), 502-516.

Rypkema, D., \& Cheong, C. (2011). Measurements and Indicators of Heritage as Development. In ICOMOS 17th General Assembly (pp. 755-762). Paris, France, 27 November.

Rypkema, D., Cheong, C., \& Mason, R. (2011). Measuring Economic Impacts of Historic Preservation. Washington, D. C.

Sabou, G. C. (2012). Sustainable Heritage Management-a Matter of National Policies Congruence. International Journal of Economic Practices and Theories, 2(3), 137142

Stubbs, M. (2004). Heritage-sustainability: developing a methodology for the sustainable appraisal of the historic environment. Planning Practice and Research, 19(3), 285-305.

Tweed, C., \& Sutherland, M. (2007). Built Cultural Heritage and Sustainable Urban Development. Landscape and Urban Planning, 83(1), $62-69$.

UNESCO. (2015). Policy Document for the Integration of a Sustainable Development Perspective into the Processes of the World Heritage Convention. UNESCO. (2017). World Heritage. Retrieved May 22, 2017, from http://whc.unesco.org/en/about/

United Nations General Assembly. (2015). Transforming our world: The 2030 agenda for sustainable development. https://sustainabledevelopment.un.org/content/documents/7891Transforming\%200ur\%20World. pdf.

Valuation and Property Services Department. (2017). Property Market Report.

Yasmin Mohd Fauzi, \& Juliza Mohamad. (2014). Architectural Interventions: A Case Study of Heritage Zone in Kota Bharu, Kelantan. TENIAT International Journal of Creative Futures and Heritage, 2(1), 133-157. 